\title{
MENGUKUR KETERAMPILAN BERFIKIR KRITIS PESERTA DIDIK TERHADAP \\ ISUE-ISUE SOSIAL MELALUI PEMANFAATAN TEKNOLOGI INFORMASI (Studi Evaluasi Pada Peserta Didik kelas IV SD Muhammadiyah Manyar)
}

\author{
Ismail Marzuki \\ Prodi PGSD, Fakultas Keguruan dan Ilmu Pendidikan, Universitas Muhammadiyah Gresik \\ Email : ismailmarzuki@umg.ac.id
}

\begin{abstract}
Abstrak
Tujuan penelitian ini adalah untuk memperoleh informasi secara mendalam tentang keterampilan berfikir kritis peserta didik terhadap isue-isue sosial dengan memanfaatkan Teknologi Informasi (TI). Jenis penelitian ini adalah penelitian evaluasi (evaluation research) dengan subjek penelitian enam siswa kelas 4 SD Muhammadiyah Manyar. Subjek tersebut terdiri atas 2 siswa dengan kecerdasan tinggi, 2 siswa dengan kecerdasan sedang, dan 2 siswa dengan kecerdasan rendah dengan jenis kelamin berbeda. Fokus penelitian adalah ingin menggali informasi tentang ketajaman berfikir kritis mereka dalam menentukan kebenaran sebuah informasi, kemampuan berargumen, dan kemampuan memecahkan masalah. Data-data penelitian dikumpulkan melalui interview dan test, dan setelah data terkumpul data kemudian dianalisis. Teknik analisis yang digunakan adalah teknik analisis deskriptifkualitatif. Hasil penelitian menunjukan bahwa pada aspek ketajaman berfikir kritis, seluruh kelompok siswa hasilnya sangat baik. Sementara untuk kemampuan berargumen kelompok dengan kecerdasan tinggi hasilnya baik, sedang kelompok sedang dan rendah hasilnya cukup. Terakhir kemampuan dalam memecahkan masalah hasilnya adalah peserta didik berkecerdasan tinggi nilainya sangat baik, sementara kelompok berkecerdasan sedang dan rendah hasilnya adalah cukup dan kurang.
\end{abstract}

Kata kunci : Teknologi informasi, isue-isue sosial

\section{PENDAHULUAN}

Terdapat beberapa keuntungan apabila dalam proses pembelajaran guru menggunakan TI. Keuntungan ini bukan hanya akan didapatkan guru, namun juga akan didapatkan peserta didik. Pertama, waktu yang diperlukan dalam proses pembelajaran akan menjadi lebih singkat, hal ini karena siswa lebih cepat dalam menuntaskan pekerjaanya (Lee dan Boyle, 2003). Hal senada disampaikan oleh Higgins et al. (2005) dalam penelitiannya terhadap 184 proses pembelajaran di sekolah dasar yang dilakukan selama dua tahun. Intinya guru yang memanfaatkan
TI dalam pembelajaran akan butuh waktu lebih pendek dibanding dengan guru yang tidak menggunakannya.

Kedua, dengan memanfaatkan TI guru akan lebih fokus pada kegiatan diskusi dan jawaban siswa (Ball, 2003), hal ini sama persis dengan temuan penelitian yang dilakukan Lavy (2002) yang menyatakan bahwa dengan memanfaatkan TI interaksi guru dan siswa akan lebih meningkat, kegiatan diskusi meningkat, penyelidikan siswa terhadap materi ajar akan lebih dalam, kontribusi siswa di kelas juga akan lebih baik, dan interaksi pembelajaran lebih sederhana. 
Ketiga, dengan memanfaatkan TI secara otomatis akan membantu guru dalam menyiapkan materi ajar dan bahan ajar yang akan disampaikan (Higgins et al. 2005).

Kelebihan ketiga apabila guru memanfaatkan TI dalam pembelajaran adalah guru dapat menyimpan catatan bahan ajar yang pernah digunakan sehingga bisa digunakan di lain waktu (Cox. et al. 2004). Adanya catatan itu menungkinkan guru untuk mengadakan perbaikan di waktu yang akan datang (Glover et al. 2007), dengan demikian melalui TI kenikmatan guru dalam mengajar akan bertambah (Solvie, 2004). Kenikmatan ini juga akan dirasakan oleh siswa dimana mereka akan merasa lebih senang dan lebih terlibat dalam proses pembelajaran, di samping menciptakan sumber daya visual yang menarik bagi guru sekaligus peserta didik (Kennewell dan Beauchamp, 2007).

Masih banyak manfaat yang akan diperoleh guru dan siswa apabila dalam proses pembelajaran mereka memanfaatkan TI, di antaranya meningkatnya interaksi siswa dengan rekan-rekannya di kelas (Elaziz, 2008), siswa dapat bekerja sama dalam kelompok untuk membahas berbagai tema sehingga dapat meningkatkan komunikasi antar siswa (Reedy, 2008). TI juga bisa meningkatnya perhatian siswa pada proses pembelajaran (Higgins et al. (2005), hal ini terjadi karena TI bisa menyediakan sumber belajar yang menarik yaitu menyediakan gambar, animasi, teks, bahkan vidio.

\section{Undang-Undang}

Republik Indonesia No. 20 Tahun 2003 tentang Sisdiknas (Sistem Pendidikan Nasional) menjelaskan bahwa tujuan pendidikan adalah untuk mengembangkan potensi peserta didik agar menjadi manusia yang beriman dan bertakwa kepada Tuhan Yang Maha Esa, berakhlak mulia, sehat, berilmu, cakap, kreatif, mandiri, dan menjadi warga negara yang demokratis serta bertanggung jawab. Berangkat dari uraian ini terlihat bahwa tujuan pendidikan adalah sebagai wahana untuk mengembangkan peserta didik agar menjadi manusia yang cakap, baik dari sisi kognitif, afektif, maupun psikomotoriknya. Gambaran peserta didik yang cakap dari sisi kognitif ini salah satunya adalah mereka yang memiliki kemampuan berfikir kritis terhadap fenomena yang ada di sekitarnya. Berangkat dari hal itu dalam menentukan tujuan pembelajaran guru hendaknya mencantumkan upaya untuk meningkatkan kemampuan berpikir kritis siswa. Keterampilan ini penting terutama untuk membantu peserta didik dalam membuat keputusan-keputusan penting dan melakukan/tidak melakukan sesuatu yang diyakini (Nur \& Wikandari:2008). 
Contoh berpikir kritis adalah mengidentifikasi iklan yang ada di telivisi apakah iklan itu benar atau salah, menyesatkan/atau tidak menyesatkan dengan menimbang bukti-bukti yang bertentangan, atau mengidentifikasi argument-argumen yang keliru. Sebagaimana belajar sebuah keterampilan berfikir kritis pun perlu dilatihkan. Seorang guru bisa melatihkan keterampilan berfikir kritis dengan memberi sejumlah dilema (dua pilihan yang sulit) kepada para siswa, dengan argumen yang logis dan tidak logis, menjelaskan iklan yang valid dan yang menyesatkan dsb. Latihan keterampilan berfikir kritis ini efektif bila ada penataan suasana diskusi yang bebas serta penerimaan terhadap pandangan yang berbeda (divergen). Berangkat dari fenomena ini peneliti bermaksud mendalamai seberapa baik keterampilan berfikir kritis peserta didik sekolah dasar terhadap isue isue sosial yang ada disekitarnya dengan memanfaatka TI.

Selama ini pemanfaatan TI khususnya bagi anak-anak masih sebatas hanya untuk kepentingan hiburan semata seperti menonton televisi, bermain komputer, dan handphone. Menonton televisi, bermain komputer, dan handphone merupakan aktivitas rutin harian anak, waktu yang dibutuhkanpun terbilang lama, hampir seluruh waktu di luar waktu sekolah dan tidur. Berdasar diskusi dengan sepuluh anak kelas 4 SD Muhammadiyah Manyar semua di antara mereka memiliki perangkat tersebut dan menghabiskan waktu lebih dari 5.5 jam sehari. Sebelum berangkat sekolah mereka melakukannya minim 0.5 jam, sepulang sekolah \pm 3 jam, dan di waktu malam sekitar 2 jam, total waktu menonton, bermain komputer, dan handphone \pm 5.5 jam. Jumlah ini tentu berbeda ketika harihari libur sekolah, karena dapat dipastikan waktu menonton dan bermain mereka akan lebih lama karena tidak ada kegiatan belajar di sekolah. Lebih menarik manakala handphone tersebut sudah tersambung dengan internet maka kecenderungan anak memanfaatkan perangkat tersebut semakin tinggi.

Di sejumlah negara seperti Inggris dan Selandia Baru penggunaan TI dalam pembelajaran telah menjadi syarat dari kurikulum formal di jenjang pendidikan dasar dan menengah, hal ini merupakan langkah maju dalam dunia pendidikan. Selama ini penelitian tentang TI terutama di jenjang pendidikan dasar masih berfokus pada dua hal yaitu pada resiko/dampak penggunaan TI dan pemanfaatan TI dalam proses belajar. Fokus pertama resiko/dampak penggunaan TI terhadap anak lebih menyoroti pada dampak positif maupun negatif penggunaan TI pada anak. Salah 
satu studi tentang hal tersebut adalah penelitian Hosokawa, Rikuya, dan Toshiki Kaatsura (2018) yang menyatakan bahwa penggunaan perangkat TI pada anak SD terlebih dilakukan tanpa pembatasan akan berdampak kurang baik pada perkembangan emosi dan sosialnya, sekaligus bisa memicu tumbuhnya perilaku bermasalah dan kurang baik pada anak.

Fokus kedua adalah pada pemanfaatan TI dalam proses belajar serta implementasi pembelajaran berbasis TI di sekolah dengan perangkat TI terbatas. Penelitian Lazaros, Edward J, Spotts, Thomas H. (2009) adalah salah satu contohnya, Penelitian ini fokus pada penggunaan TI (komputer) untuk pengembangan proses pembelajaran mata pelajaran tertentu seperti sains, matematia, bahasa dan seni. Mengomentari hasil penelitian Hosokawa, Rikuya, dan Toshiki Kaatsura (2018) ini sesungguhnya teknologi informasi itu bersifat netral, bisa berdampak negatif sekaligus juga bisa berdampak positif, sangat tergantung pada manajemen penggunaanya. Apabila TI digunakan secara terencana dan terprogram serta dengan pendampingan yang baik, maka hasilnya akan baik, namun bila penggunaan TI dilakukan secara asal, tanpa perencanaan, dan pengawasan maka bisa jadi hasilnya akan buruk.
Kedua penelitian Lazaros, Edward J, Spotts, Thomas H. (2009) yang hanya fokus pada penggunaan TI (komputer) untuk pengembangan proses pembelajaran sains, matematia, bahasa dan seni, maka penelitian ini akan lebih lengkap manakala TI juga digunakan untuk mengembangkan mata pelajaran bermuatan sosial. Belum banyak penelitian yang konsen terhadap pemanfaatan TI ini terutama untuk pengembangan keterampilan dasar berfikir kritis agar peserta didik peka terhadap isue-isue sosial, padahal keterampilan ini penting untuk menjadikannya sebagai anggota masyarakat yang baik. Tujuan penelitian ini adalah untuk memperoleh informasi secara mendalam tentang dampak dan pengaruh teknologi informasi yang digunakan dalam pembelajaran ilmu-ilmu sosial di sekolah dasar, lebih spesifik terkait dengan keterampilan dasar berfikir kritisnya terhadap isue isue sosial yang ada di sekitarnya.

Selama ini disiplin ilmu-ilmu sosial di sekolah dasar sering disajikan dengan rujukan materi dari buku (teks book) dan pengalaman hidup guru dan peserta didik. Kedua sumber itu tentu memiliki banyak keterbatasan karena bisa jadi buku tersebut dicetak beberapa tahun yang lalu sehingga isinya kurang up to date atau pengalaman guru dan peserta didik yang 
terbatasi oleh wilayah dan daerah tertentu, maka pemanfaatan sumber dan media belajar dari perangkat teknologi informasi secara otomatis akan mengatasi hal-hal tersebut.

Hal ini karena tujuan mata pelajaran Ilmu Pengetahuan Sosial (IPS) adalah membekali peserta didik agar mereka memiliki kemampuan berfikir logis, kritis, bisa memecahkan masalah, dan terampil dalam kehidupan sosialnya. Informasi yang mendalam tentang dampak dan pengaruh teknologi informasi dalam pembelajaran pada ilmu-ilmu sosial di sekolah dasar ini tentu memiliki arti penting. Terlebih informasi itu terkait dengan keterampilan dasar berfikir kritis peserta didik terhadap isue isue sosial yang ada di masyarakatnya. Penelitian ini diharapkan memiliki kontribusi mendasar tentang pentingnya sekolah mengimplementasikan pembelajaran ilmu-ilmu sosial dengan pendekatan berbasis teknologi informasi.

\section{TINJAUAN PUSTAKA}

\section{A. Pemanfaatan TI dalam Pembelajaran}

Teknologi informasi (TI)
adalah sarana prasarana yang
menyediakan layanan informasi
untuk kenyamanan kehidupan
manusia (KBBI, 2014). Perangkat TI
seperti televisi, komputer, internet,

telepon seluler, atau yang lain adalah sarana prasarana yang menyediakan layanan ini. Perangkat ini mengolah berbagai informasi dan mendistribusikannya dalam bentuk digital. Perangkat ini merupakan bagian penting dalam kehidupan manusia termasuk anak-anak dan keberadaannya tidak bisa dipisahkan dari kehidupan masyarakat modern saat ini (Macedo, 2013).

Di berbagai negara seperti Amerika, Ingggris, Selandia Baru, dan Hongkong perangkat teknologi informasi telah lama digunakan untuk mendukung proses pembelajaran di kelas (Wise, 2010). Kehadiran TI sedikit banyak telah membantu, mewarnai, mempengaruhi, bahkan mengubah potret pendidikan di negara-negara tersebut. Perubahan itu terjadi terutama pada proses dan pendekatan dalam pembelajaran (Savage, 2007). Pemanfaatan TI dalam pembelajaran memang tengah menjadi tema kajian, diskusi, dan penelitian di berbagai negara saat ini. Fokus kajian, diskusi, dan penelitian itu adalah bagaimana TI bisa dimanfaatkan dan digunakan untuk meningkatkan kualitas pembelajaran. Berbagai studi menunjukan bahwa TI telah menjadi kebutuhan dan bagian penting dari proses pembelajaran. 
Ketika guru mengajar dengan TI maka yang bersangkutan akan punya kesempatan lebih banyak untuk berfikir dan berefleksi, dengan demikian proses belajar yang ia lakukan akan lebih mudah dan efisien (Kaufman, 1998. Meski demikian TI bukanlah yang paling utama TI hanya merupakan media agar proses belajar bisa lebih cepat, lebih murah, dan lebih baik.

Keberadaaan TI di sekolah saat ini menjadi sesuatu yang penting. Zucker (2009) menyebut ada 5 alasan mengapa TI menjadi penting bagi sekolah. Pertama, karena perangkat TI itu harganya terjangkau dan semakin murah hal ini ditandai dengan semakin meluasnya pengguna perangkat tersebut dan hampir bisa dipastikan bahwa setiap sekolah bahkan keluarga telah memilikinya; Kedua, melalui world wide web (www) sekolah atau guru akan lebih mudah mengakses informasi karena informasi apapun tersedia di situ; Ketiga, informasi yang diberikan oleh mesin pencari (browser) bisa diperoleh dalam berbagai bentuk seperti teks, gambar, suara, dan vidio. Keempat, internet saat ini telah menjadi jembatan dunia, dengan internet seseorang dapat dengan mudah berkomunikasi dengan orang lain di belahan dunia yang jauh sekalipun; Kelima internet saat ini memberi banyak layanan tak berbayar (gratis) dan bisa disambungkan dengan komputer yang memudahkan setiap penggunanya. Berangkat dari fenomena di atas, maka guru zaman kini harus mampu mengintegrasikan TI dalam pengajaran di kelasnya (Kain, 2004).

\section{B. Keterampilan Dasar Berfikir Kritis}

Sebelum membahas pengertian berfikir kritis, terlebih dahulu yang harus dipahami adalah makna istilah berfikir dan istilah kritis itu sendiri. Berfikir dalam KBBI (2014) dijelaskan sebagai kegiatan yang menggunakan akal budi untuk mempertimbangkan atau memutuskan sesuatu, sedang kritis diartikan sebagai berfikir yang tajam, tidak lekas percaya dan selalu berusaha untuk menemukan sebuah kesalahan atau kekeliruan. Berangkat dari definisi ini dapat disimpulkan bahwa berfikir kritis adalah berfikir dengan menggunakan akal budi untuk memutuskan sesuaatu dengan analisis yang tajam agar terhindar dari kesalahan dan kekeliruan.

Ennis (1996) mendefinisikan berfikir kritis sebagai proses berfikir yang bertujuan membuat keputusan yang masuk akal mengenai sesuatu 
yang diyakini kebenarannya serta akan dilakukannya nanti. Berpikir kritis adalah cara pengambilan keputusan tingkat tinggi yang difokuskan pada sesuatu yang akan dipercaya atau tidak dipercaya, sesuatu yang akan dilakukan atau tidak dilakukan. Karakter sikap ini adalah sikap berhati-hati ketika akan menerima atau menolak sesuatu. Berfikir kritis adalah sikap berfikir yang netral, objektif, beralasan, dan logis (Darmawan, 2010), seseorang bisa dikatakan berpikir kritis bila ia mampu menganalisis argumen secara cermat, mencari bukti-bukti yang sah, dan mampu menghasilkan keputusan yang mantap untuk mempercayai/tidak mempercayai sesuatu.

Berpikir kritis merupakan keterampilan yang penting, oleh karena itu Tilaar (2000) menyebut beberapa alasan tentang pentingnya keterampilan ini dikembangkan di sekolah. Pertama, mengembangkan keterampilan ini berarti memberi penghargaan kepada peserta didik sebagai pribadi. Kedua, mengembangkan keterampilan ini berarti mempersiapkan peserta didik untuk hidup secara dewasa. Ketiga, mengembangkan keterampilan ini berarti melaksanakan cita-cita dan tujuan utama belajar yang ingin dicapai, dan ke empat mengembangkan keterampilan ini berarti memberi bekal peserta didik untuk bisa eksis dalam kehidupan berdemokrasi.

Berpikir kritis merupakan keterampilan yang bisa dilatihkan dan dikembangkan. Bonnie dan Potts (2003) menyebut ada tiga strategi pengembangan keterampilan berpikir kritis; 1) building categoris (membuat kategori), 2) finding problem (menemukan masalah), 3 enchanching the envionrenment (mengondusifkan lingkungan). Strategi lain pengembangan keterampilan berpikir kritis adalah dengan memberi pertanyaanpertanyaan sambil membimbing siswa mengaitkan dengan konsepkonsep yang telah dimiliki. Seorang guru bisa kapanpun melatihkan keterampilan berfikir kritis ini dan ciri guru yang mengajarkan keterampilan berfikir kritis adalah : 1) meningkatkan interaksi di antara siswa, 2) mengajukan pertanyaan open ended, 3) memberi waktu berpikir untuk menjawab pertanyaan, 4) teaching for transfer (mengajar untuk menggunakan kemampuan yang baru diperoleh pada situasi tertentu). 
Krulik \& Rudnic

(Siswono,2009)

membagi

keterampilan berfikir menjadi empat tingkatan:1) berpikir menghafal (recalling thinking), berpikir dasar (basic thinking), berpikir kritis (critical thinking), berpikir kreatif (creative thinking). Setiap manusia memiliki kemampuan berfikir yang beragam, artinya manusia yang satu dengan lainnya memiliki kemampuan berfikir yang berbeda. Keterampilan berfikir kritis disebut sebagai keterampilan berfikir ketiga, yang hal itu berarti cukup penting, karena berfikir kritis dapat melejitkan kemampuan dalam memecahkan masalah, menjauhkan seseorang dari ketimpangan berfikir, dan menuntun seseorang berfikir logis dan rasional.

Fokus latihan berfikir kritis hendaknya lebih menekankan pada pemberian alasan atau pandangan seseorang bukan sekedar mengharap jawaban yang benar. Keterampilan berfikir kritis bisa dicapai siswa bila berkaitan dengan topik-topik yang telah mereka kenal, dan yang lebih penting tujuan pembelajaran berfikir kritis adalah menciptakan semangat berfikir kritis dan mendorong mereka untuk selalu mempertanyakan terhadap apa yang mereka dengar, mereka fikirkan bahwa idak terjadi kekeliruan logika di dalamnya. Ada sepuluh keterampilan dalam berfikir kritis yang dapat digunakan siswa untuk mempertimbangkan keabsahan tuntutan, argumen, atau memahami sebuah peristiwa, yaitu :

a. membedakan fakta yang dapat diuji kebenarannya dan tuntutan nilai yang sulit diuji kebenarannya;

b. membedakan antara informasi, tuntutan, atau alasan yang relevan dengan yang tidak relevan;

c. mengidentifikasi asumsi yang tidak dinyatakan;

d. menentukan kredibilitas dari suatu sumber;

e. mengidentifikasi kekeliruan logika; mendeteksi penyimpanagan;

f. menentukan kekuatan suatu argument;

g. mengenali ketidakkonsistenan logika dalam alur penalaran;

h. mengidentifikasi argumen yang mendua;

i. menentukan kebenaran dari suatu pernyataan;

j. menemukan penyimpangan.

Kesepuluh keterampilan ini adalah daftar cara yang mungkin bisa dilakukan untuk mengevaluasi apakah informasi itu benar atau tidak, atau masuk akal atau tidak. Tugas utama mengajarkan berfikir kritis ini 
adalah tidak hanya bagaimana menggunakan tiap-tiap strategi ini tetapi menyampaikan kapan tiap strategi itu cocok untuk dipakai. Keterampilan ini penting terutama untuk memecahkan masalah, membuat keputusan, atau mencari kebenaran, di tengah pesatnya kemajuan teknologi informasi. Keterampilan ini sangat diperlukan sebagai daya saring terhadap informasi, berita, dan isue yang datang silih berganti. Keterampilan ini penting karena dapat juga melejitkan kemampuan anak dalam memecahkan masalah, menjauhkan dari ketimpangan berfikir, dan menuntun mereka berfikir secara logis dan rasional. Melihat pentingnya kemampuan ini, maka sekolah diharapkan bisa melatih dan mengembangkannya.

\section{METODE PENELITIAN}

Jenis penelitian ini adalah penelitian evaluasi (evaluation research) yang akan menyelidiki secara mendalam tentang dampak pemanfaatan teknologi informasi terhadap keterampilan berfikir kritis peserta didik terhadap permasalahan atau isue-isue sosial yang disajikan kepadanya. Subjek penelitiannya enam peserta didik kelas 4 SD Muhammadiyah Manyar, di antara mereka merupakan 2 peserta didik dengan kecerdasan tinggi, 2 dengan kecerdasan sedang, dan 2 dengan kecerdasan rendah. Masing-masing dari mereka adalah berasal dari jenis kelamin berbeda.

Data-data penelitian diperoleh melalui hasil interview dan tes terhadap enam subjek penelitian tersebut. Peneliti juga akan melibatkan diri dalam proses pembelajaran pada tema "Indahnya Keragaman Negeriku" sub tema "Indahnya Persatuan dan Kesatuan Negeriku" di kelas. Tema ini merupakan tema ke 7 dan sub tema ke 3 pada kurukulium 2013 di kelas 4. Pada proses pembelajaran peneliti akan menayangkan film seputar dampak pemilihan kepala desa yang di dalamnya terdapat ancaman terhadap persatuan dan kesatuan bangsa. Perangkat IT yang digunakan peneliti adalah komputer, infocus, dan sound system.

Setelah melihat tayangan tersebut peneliti melakukan interview dan tes untuk mendalami keterampilan peserta didik dalam menentukan sebuah kebenaran informasi, melihat kemampuannya berargumentasi, serta menyelidiki kemampuannya memecahkan masalah. Interview dilakukan terpisah agar jawaban subjek penelitian tidak saling terpengaruh di antara mereka. Melalui interview dan tes ini peneliti berharap bisa mendapatkan informasi 
sebanyak-banyaknya sehingga hasil penelitian bisa mendalam. Penekanan informasi yang akan digali ini adalah: 1) ketajaman mereka dalam berfikir, 2) kemampuan mereka dalam berargumen, serta 3) kemampuan mereka memecahkan masalah sosial yang diajukan kepadanya.

Oleh karena teknik pengumpulan datanya melalui interview dan tes maka peneliti telah menyusun instrument untuk dijadikan alat sebagai panduan di lapangan. Alat tersebut adalah pedoman interview dan lembar soal yang akan dikerjakan peserta didik. Berikut adalah uraian atau tabel pedoman interview dan soal soal yang akan dikerjakan peserta didik.

\section{PEDOMAN INTERVIEW}

\begin{tabular}{|c|c|c|c|c|c|c|}
\hline \multirow{2}{*}{ NO } & \multirow{2}{*}{ PERTANYAAN } & \multicolumn{5}{|c|}{ NILAI } \\
\hline & & 5 & 4 & 3 & 2 & 1 \\
\hline & $\begin{array}{l}\text { KETAJAMAN } \\
\text { BERFIKIR }\end{array}$ & & & & & \\
\hline 1 & $\begin{array}{l}\text { Percayakah kamu tentang } \\
\text { kebenaran tayangan tadi! }\end{array}$ & & & & & \\
\hline 2 & $\begin{array}{l}\text { Bolehkan pendukung calon } \\
\text { kades yang gagal tersebut } \\
\text { berbuat kerusuhan! }\end{array}$ & & & & & \\
\hline 3 & $\begin{array}{l}\text { Betulkah tidakan yang } \\
\text { dilakukan calon kades yang } \\
\text { kalah tersebut }\end{array}$ & & & & & \\
\hline 4 & $\begin{array}{l}\text { Setujukah kamu dengan } \\
\text { tindakan yang dilakukan } \\
\text { calon kades yang gagal } \\
\text { tersebut? }\end{array}$ & & & & & \\
\hline 5 & $\begin{array}{l}\text { Benarkah yang dilakukan } \\
\text { penduduk tadi ketika } \\
\text { berdemo! }\end{array}$ & & & & & \\
\hline & $\begin{array}{l}\text { KEMAMPUAN } \\
\text { BERARGUMEN }\end{array}$ & & & & & \\
\hline 6 & $\begin{array}{l}\text { Mengapa kamu percaya/tak } \\
\text { percaya tentang kebenaran } \\
\text { tayangan tadi! }\end{array}$ & & & & & \\
\hline 7 & $\begin{array}{l}\text { Mengapa pendukung calon } \\
\text { kades yang gagal tersebut } \\
\text { tidak boleh berbuat } \\
\text { kerusuhan! }\end{array}$ & & & & & \\
\hline 8 & $\begin{array}{l}\text { Mengapa tidakan yang } \\
\text { dilakukan calon kades yang } \\
\text { kalah tadi dikatakan salah! }\end{array}$ & & & & & \\
\hline 9 & $\begin{array}{l}\text { Mengapa kamu setuju/tidak } \\
\text { setuju dengan tindakan yang } \\
\text { dilakukan calon kades yang } \\
\text { gagal tersebut! }\end{array}$ & & & & & \\
\hline 10 & $\begin{array}{l}\text { Mengapa berbuat kerusuhan } \\
\text { setelah pilkades dilarang! }\end{array}$ & & & & & \\
\hline & $\begin{array}{l}\text { KEMAMPUAN } \\
\text { MEMECAHKAN } \\
\text { MASALAH. }\end{array}$ & & & & & \\
\hline 11 & $\begin{array}{l}\text { Sebutkan apa yang harus } \\
\text { dilakukan polisi ketika } \\
\text { terjadi kerusuhan!. }\end{array}$ & & & & & \\
\hline 12 & $\begin{array}{l}\text { Sebutkan apa yang harus } \\
\text { dilakukan anak kecil ketika } \\
\text { terjadi kerusuhan! }\end{array}$ & & & & & \\
\hline
\end{tabular}

\begin{tabular}{|c|l|c|c|c|c|c|}
\hline 13 & $\begin{array}{l}\text { Sebutkan apa yang harus } \\
\text { dilakukan terhadap sepeda } \\
\text { motor ketika terjadi } \\
\text { kerusuhan! }\end{array}$ & & & & & \\
\hline 14 & $\begin{array}{l}\text { Sebutkan apa yang harus } \\
\text { dilakukan ibu ibu ketika } \\
\text { terjadi kerusuhan! }\end{array}$ & & & & & \\
\hline 15 & $\begin{array}{l}\text { Sebutkan apa yang harus } \\
\text { dilakukan pak lurah ketika } \\
\text { terjadi kerusuhan! }\end{array}$ & & & & & \\
\hline
\end{tabular}

Setelah data terkumpul langkah peneliti selanjutnya adalah analisis data. Teknik analisis yang digunakan adalah analisis data deskriptif kualitatif, yaitu teknik analisis yang menggunakan "tolok ukur" atau "kriteria" di dalamnya. Tolok ukur digunakan untuk menilai sejauh mana variabel penelitian sesuai dengan kriteria yang telah ditetapkan. Setelah menentukan tolok ukur/kriteria peneliti kemudian menentukan "nilai" yang disesuaikan dengan rumusan tolok ukur. Untuk mengukur keterampilan berfikir kritis peserta didik, peneliti menentukan tiga indikator yaitu: 1) ketajaman berfikir, 2) kemampuan berargumen, 3) kemampuan memecahkan permasalahan sosial.

Ketiga indikator itu masing-masing akan dijabarkan menjadi lima pertanyaan yang terdapat pada instrumen penelitian. Pada instrumen juga telah disediakan kolom penilaian dalam bentuk skor yang disusun berjenjang dari yang tertiggi (skor 5) sampai terendah (skor 1). Pemberian nilai dilakukan bersamaan ketika melakukan wawancara. Jika skor maksimal tiap butir pertanyaan 5 maka skor nilai tiap indikator adalah 25 sehingga jumlah skor maksimal secara 
keseluruhan adalah 75. Skor yang diperoleh tiap subjek penelitian akan dikonversikan ke dalam lima kategori yaitu "Sangat Baik", "Baik", "Cukup", "Kurang", dan "sangat kurang". Oleh karena skor maksimal adalah 75 maka rentangan skor masing-masing kategori adalah sebagai berikut: Sangat Baik (6175), Baik (46-60), Cukup (31-45), Kurang (16-30), Sangat Kurang (1-15). Demikian pula nilai kategori tiap-tiap indikator juga akan dikonversikan, oleh karena skor maksimal tiap-tiap indikator adalah 25 maka kategorinya adalah: Sangat Baik (21-25), Baik (16-20), Cukup (11-15), Kurang (6-10), Sangat Kurang (1-5).

Setelah mengetahui kemampuan berfikir kritis masing-masing anak berdasar perolehan skornya, peneliti kemudian melakukan rekapitulasi skor terhadap 6 subjek penelitian. Hasil rekapitulasi itu kemudian dirata-rata dan ditentukan kategori berfikir kritis anak secara keseluruhan. Untuk mempermudah memahami laporan penelitian peneliti menyajikan data penelitian dalam bentuk diagram batang.

\section{HASIL PENELITIAN}

Penelitian ini dilakukan selama kurang lebih 2 bulan, mulai awal bulan April hingga akhir bulan Mei 2019. Selama 2 bulan tersebut peneliti melakukan pembelajaran dengan menggunakan perangkat teknologi informasi seperti komputer, LCD, sound sistem dan sumber materi yang diakses dari internet. Materi tersebut berupa artikel, opini, kolom, dan video yang diambil dari google dan laman youtube. Sumber materi dipilih dan dipilahpilah penelti dengan hanya mengambil yang bersesuaian dengan tujuan pembelajaran. Hal itu dimaksudkan agar konten bersesuaian dengan tema dan tujuan pembelajaran yang telah disusun sebelumnya. Resources atau sumber belajar yang diakses dari internet tersebut diharapkan bisa mendekatkan antara konsep teori yang dipelajari peserta didik dengan dunia nyata.

Selama empat kali pembelajaran dua di antaranya peneliti melakukan evaluasi pembelajaran. Evaluasi pertama dilakukan dengan teknik tes tulis sedang evaluasi kedua dilakukan dengan interview. Tema materi yang dievaluasi adalah indahnya persatuan dan kesatuan negeriku, dimana tema ini merupakan tema ke tujuh sub tema ketiga kelas 4 sekolah dasar. Berikut adalah tabel hasil evaluasi dari masing-masing subjek penelitian.

Tabel 1. Hasil Evaluasi

\begin{tabular}{|c|c|c|c|c|}
\hline \multirow{2}{*}{ RESPONDEN } & \multirow{2}{*}{$\begin{array}{c}\text { ASPEK } \\
\text { KETERAMPILAN } \\
\text { BERFIKIR KRITIS }\end{array}$} & \multicolumn{3}{|c|}{ SKOR } \\
\hline & & MAKS & $\begin{array}{c}\text { HASIL } \\
\text { INTERVIEW }\end{array}$ & $\begin{array}{l}\text { HASIL } \\
\text { TES } \\
\text { TULIS }\end{array}$ \\
\hline \multirow{4}{*}{1} & Ketajaman berfikir & 25 & 25 & 25 \\
\hline & $\begin{array}{l}\text { Kemampuan } \\
\text { berargumen }\end{array}$ & 25 & 20 & 20 \\
\hline & $\begin{array}{l}\text { Kemampuan } \\
\text { memecahkan masalah }\end{array}$ & 25 & 25 & 25 \\
\hline & Jumlah & 75 & 70 & 70 \\
\hline \multirow{4}{*}{2} & Ketajaman berfikir & 25 & 25 & 25 \\
\hline & $\begin{array}{l}\text { Kemampuan } \\
\text { berargumen }\end{array}$ & 25 & 20 & 20 \\
\hline & $\begin{array}{l}\text { Kemampuan } \\
\text { memecahkan masalah }\end{array}$ & 25 & 25 & 25 \\
\hline & Jumlah & 75 & 70 & 70 \\
\hline \multirow{4}{*}{3} & Ketajaman berfikir & 25 & 25 & 25 \\
\hline & $\begin{array}{l}\text { Kemampuan } \\
\text { berargumen }\end{array}$ & 25 & 10 & 10 \\
\hline & $\begin{array}{l}\text { Kemampuan } \\
\text { memecahkan masalah }\end{array}$ & 25 & 20 & 20 \\
\hline & Jumlah & 75 & 55 & 55 \\
\hline \multirow{4}{*}{4} & Ketajaman berfikir & 25 & 25 & 25 \\
\hline & $\begin{array}{l}\text { Kemampuan } \\
\text { berargumen }\end{array}$ & 25 & 15 & 15 \\
\hline & $\begin{array}{l}\text { Kemampuan } \\
\text { memecahkan masalah }\end{array}$ & 25 & 15 & 20 \\
\hline & Jumlah & 75 & 55 & 60 \\
\hline \multirow[b]{2}{*}{5} & Ketajaman berfikir & 25 & 20 & 20 \\
\hline & $\begin{array}{l}\text { Kemampuan } \\
\text { berargumen }\end{array}$ & 25 & 10 & 0 \\
\hline
\end{tabular}




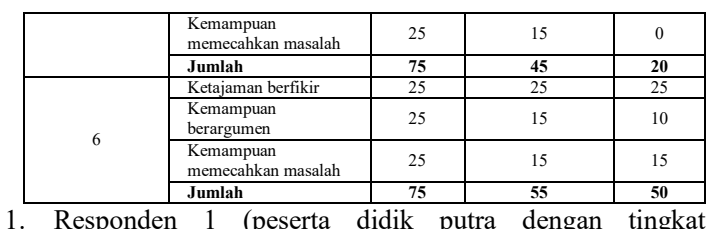

1. Responden 1 (peserta didik putra dengan tingkat kecerdasan tinggi)

2. Responden 2 (peserta didik putri dengan tingkat kecerdasan tinggi)

3. Responden 3 (peserta didik putra dengan tingkat kecerdasan sedang)

4. Responden 4 (peserta didik putri dengan tingkat kecerdasan sedang)

5. Responden 5 (peserta didik putra dengan tingkat kecerdasan rendah)

6. Responden 6 (peserta didik putri dengan tingkat kecerdasan rendah)

Dari hasil evaluasi tersebut terlihat bahwa terdapat perbedaan kemampuan berfikir kritis di antara enam subjek penelitian. Apabila skor tiap-tiap indikator tersebut dikonversikan ke dalam nilai dengan rentang nilai : 21-25 (Sangat Baik), 16-20 (Baik), 11-15 (Cukup), 6-10 (Kurang), 0-5 (Sangat Kurang), maka tabel konversi nilainya adalah sebagai berikut.

Tabel 2. Konversi Nilai Tiap Aspek

\begin{tabular}{|c|c|c|c|}
\hline \multirow{2}{*}{ RESPONDEN } & \multirow{2}{*}{$\begin{array}{c}\text { ASPEK } \\
\text { KETERAMPILAN } \\
\text { BERFIKIR KRITIS }\end{array}$} & \multicolumn{2}{|c|}{ KONVERSI NILAI } \\
\hline & & $\begin{array}{c}\text { HASIL } \\
\text { INTERVIEW }\end{array}$ & $\begin{array}{c}\text { HASIL } \\
\text { TES } \\
\text { TULIS }\end{array}$ \\
\hline \multirow{3}{*}{$\begin{array}{c}\text { RESPONDEN } \\
1\end{array}$} & Ketajaman berfikir & Sangat Baik & $\begin{array}{c}\text { Sangat } \\
\text { Baik }\end{array}$ \\
\hline & $\begin{array}{l}\text { Kemampuan } \\
\text { berargumen }\end{array}$ & Baik & Baik \\
\hline & $\begin{array}{l}\text { Kemampuan } \\
\text { memecahkan masalah }\end{array}$ & Sangat Baik & $\begin{array}{c}\text { Sangat } \\
\text { Baik }\end{array}$ \\
\hline \multirow{3}{*}{$\begin{array}{c}\text { RESPONDEN } \\
2\end{array}$} & Ketajaman berfikir & Sangat Baik & $\begin{array}{c}\text { Sangat } \\
\text { Baik }\end{array}$ \\
\hline & $\begin{array}{l}\text { Kemampuan } \\
\text { berargumen }\end{array}$ & Baik & Baik \\
\hline & $\begin{array}{l}\text { Kemampuan } \\
\text { memecahkan masalah }\end{array}$ & Sangat Baik & $\begin{array}{c}\text { Sangat } \\
\text { Baik } \\
\end{array}$ \\
\hline \multirow{3}{*}{$\begin{array}{c}\text { RESPONDEN } \\
3\end{array}$} & Ketajaman berfikir & Sangat Baik & $\begin{array}{c}\text { Sangat } \\
\text { Baik } \\
\end{array}$ \\
\hline & $\begin{array}{l}\text { Kemampuan } \\
\text { berargumen }\end{array}$ & Kurang & Kurang \\
\hline & $\begin{array}{l}\text { Kemampuan } \\
\text { memecahkan masalah }\end{array}$ & Baik & Baik \\
\hline \multirow{3}{*}{$\begin{array}{c}\text { RESPONDEN } \\
4\end{array}$} & Ketajaman berfikir & Sangat Baik & $\begin{array}{c}\text { Sangat } \\
\text { Baik }\end{array}$ \\
\hline & $\begin{array}{l}\text { Kemampuan } \\
\text { berargumen }\end{array}$ & Cukup & Cukup \\
\hline & $\begin{array}{l}\text { Kemampuan } \\
\text { memecahkan masalah }\end{array}$ & Cukup & Baik \\
\hline \multirow{3}{*}{$\begin{array}{l}\text { RESPONDEN } \\
5\end{array}$} & Ketajaman berfikir & Baik & Baik \\
\hline & $\begin{array}{l}\text { Kemampuan } \\
\text { berargumen }\end{array}$ & Kurang & $\begin{array}{r}\text { Sangat } \\
\text { Kurang } \\
\end{array}$ \\
\hline & $\begin{array}{l}\text { Kemampuan } \\
\text { memecahkan masalah }\end{array}$ & Cukup & $\begin{array}{l}\text { Sangat } \\
\text { Kurang }\end{array}$ \\
\hline \multirow{3}{*}{$\begin{array}{c}\text { RESPONDEN } \\
6\end{array}$} & Ketajaman berfikir & Sangat Baik & $\begin{array}{c}\text { Sangat } \\
\text { Baik } \\
\end{array}$ \\
\hline & $\begin{array}{l}\text { Kemampuan } \\
\text { berargumen }\end{array}$ & Cukup & Kurang \\
\hline & $\begin{array}{l}\text { Kemampuan } \\
\text { memecahkan masalah }\end{array}$ & Cukup & Cukup \\
\hline
\end{tabular}

Sementara apabila skor di atas di total dan dikonversikan dengan kategori nilai dengan rentang nilai : 61-75 (Sangat Baik), 46-60 (Baik), 31-45 (Cukup), 1630 (Kurang), 1-15 (Sangat Kurang), maka hasilnya adalah sebagaimana berikut.

Tabel 3. Konversi Nilai Secara Total

\begin{tabular}{|c|c|c|c|}
\hline \multirow{2}{*}{ NO } & \multirow{2}{*}{ RESPONDEN } & \multicolumn{2}{|c|}{ KONVERSI NILAI } \\
\cline { 3 - 4 } & & HASIL & $\begin{array}{c}\text { HASIL } \\
\text { TES TULIS }\end{array}$ \\
\hline 1 & RESPONDEN 1 & Sangat Baik & Sangat Baik \\
\hline 2 & RESPONDEN 2 & Sangat Baik & Sangat Baik \\
\hline 3 & RESPONDEN 3 & Baik & Baik \\
\hline 4 & RESPONDEN 4 & Baik & Baik \\
\hline 5 & RESPONDEN 5 & Cukup & Kurang \\
\hline 6 & RESPONDEN 6 & Baik & Baik \\
\hline
\end{tabular}

\section{DISKUSI HASIL PENELITIAN}

Pada saat peneliti mencari materi ajar yang akan disampaikan dalam proses pembelajran peneliti tidak mengalami kesulitan sedikitpun. Hal ini sama dengan apa yang disampaikan oleh Zucker (2009) menyebut ada 5 melalui world wide web (www) guru atau sekolah akan lebih mudah mengakses informasi karena informasi apapun tersedia di situ, dengan mesin pencari (browser) materi ajar bisa diperoleh dalam berbagai bentuk seperti teks, gambar, suara, dan video. Satu hal yang lebih menggembirakan bahwa layanan internet tersebut saat ini bisa dikases dengan layanan tak berbayar (gratis). Layanan tersebut bisa disambungkan langsung dengan komputer di kelas dan hal ini tentu sangat 
memudahkan bagi setiap guru yang menggunakannya.

Terdapat beberapa keuntungan lain apabila guru dalam proses pembelajaran menggunakan TI di antaranya waktu yang diperlukan dalam proses pembelajaran akan menjadi lebih singkat (Lee dan Boyle, 2003). Hal senada juga disampaikan oleh Higgins et al. (2005) yang intinya guru yang memanfaatkan TI dalam pembelajaran akan butuh waktu lebih pendek dibanding dengan guru yang tidak menggunakannya. Kedua, dengan memanfaatkan TI guru akan lebih fokus pada kegiatan diskusi dan jawaban siswa (Ball, 2003).

Hal serupa persis dengan temuan penelitian sebelumnya yang dilakukan Levy (2002) yang menyatakan bahwa dengan memanfaatkan TI interaksi guru dan siswa akan lebih meningkat, kegiatan diskusi meningkat, penyelidikan siswa terhadap materi ajar akan lebih dalam, kontribusi siswa di kelas juga akan lebih baik, dan interaksi pembelajaran lebih seerhana. Ketiga, dengan memanfaatkan TI secara otomatis akan membantu guru dalam menyiapkan materi ajar dan bahan ajar yang akan disampaikan (Higgins et al. 2005).

Tema pembelajaran adalah indahnya persatuan dan kesatuan negeriku yang merupakan tema ke tujuh dan sub tema yang ketiga di kelas 4 sekolah dasar merupakan tema yang penting dan aktual. Melalui internet peneliti bisa langsung mencari materi ajar yang bisa diintegrasikan dengan tema tersebut sebagaimana kata Kain (2004) yang menyatakan bahwa guru zaman kini harus mampu mengintegrasikan TI dalam pengajaran di kelasnya. Mengacu pada definisi berfikir kritis (KBBI, 2011) dimana disebutkan bahwa berfikir kritis adalah berfikir dengan menggunakan akal budi untuk memutuskan sesuaatu dengan analisis yang tajam agar terhindar dari kesalahan dan kekeliruan, maka hasil penelitian telah menunjukan kearah tersebut.

Hasil penelitian menunjukan bahwa keenam responden telah 100\% mampu membuat keputusan bahwa tayangan film itu bisa dipercaya atau tidak dapat dipercaya. Hal ini pernah disampaikan Ennis (1996) mengidentifikasi bahwa berfikir kritis sebagai proses berfikir untuk membuat keputusan yang masuk akal atau tidak masuk akal. Hanya pada responden putra dengan tingkat kecerdasan rendah yang masih belum mampu secara sempurna memutuskan apa yang akan dilakukannya terhadap fenomena yang diajukan. Mengenai kemampuan membuat dan menganalisis argumen dengan tepat hasil penelitian menunjukan bahwa responden masih belum 
menyampaikan argumentasinya secara lengkap dan terinci.

\section{PENUTUP}

\section{A. Simpulan}

Berdasar hasil penelitian yang telah dibahas pada bab sebelumnya maka simpulan penelitian ini adalah:

1. Pada aspek ketajaman berfikir kritis terutama terkait kemampuan peserta didik dalam membedakan fakta atau opini, benar atau salah, boleh atau tidak boleh, setuju atau tidak setuju, kemampuan mereka mencapai nilai sangat baik.

2. Pada aspek kemampuan berargumen peserta didik dari kelompok kecerdasan tinggi telah mampu mencapai nilai baik, sementara dari kelompok berkecerdasan sedang dan rendah capaiannya adalah pada nilai cukup dan kurang.

3. Pada aspek pemecahkan masalah peserta didik berkecerdasan tinggi telah mampu mencapai nilai sangat baik, sementara dari kelompok berkecerdasan sedang dan rendah capaiannya adalah pada nilai cukup dan kurang.

\section{B. Saran}

Saran yang bisa disampaikan peneliti mengacu pada hasil penelitian ini adalah:
1. Perlunya sekolah dan guru mengembangkan proses pembelajaran yang mengembangkan keterampilan berfikir kritis peserta didik terutama terkait fenomena dan issue-isue sosial yang ada di sekitarnya.

2. Ada dua aspek keterampilan berfikir kritis peserta didik yang perlu dikembangkan yaitu kemampuan mereka dalam berargumen terhadap pilihan pendapat yang dipilih serta kemampuan dalam memecahkan masalah yang diajukan kepadanya.

\section{DAFTAR PUSTAKA}

Ball, B. (2003) 'Teaching and learning mathematics with an interactive whiteboard', Micromaths, 19, pp. 4-7.

Bonnie dan Potts. (2003). Strategi for Teaching Critical Thinking, Practical Assesment, Research \& Evaluation. Online. Tersedia: http: // www . edresearch .org/ pare/ getvn. asp? $\quad \mathrm{v}=47 \mathrm{n}=3$ (diakses tanggal 17 Juni 2017.

Cox, M., Abbot, C., Webb, M., Blakeley, B., Beauchamp, T. and Rhodes, V. (2004) ICTand Attainment: A Review of the Research Literature . Available at: http:// 
www.becta.org.uk/page_documents /research/ict_attainment (Accessed: 15 Jan 2018).

Darmawan. 2010. Penggunaan Pembelajaran Berbasis Masalah dalam Meningkatkan Kemampuan Berpikir Kritis Siswa. Jurnal Penelitian Pendidikan Vol. 11 No. 2 Oktober 2010.

Depdikbud. 2014. Kamus Besar Bahasa Indonesia. Jakarta: Balai Pustaka.

Ennis, R.H. 1996. Critical Thinking. New Jersey: Prentice-Hall Inc.

Glover, D., Miller, D., Averis, D. and Door, V. (2007) 'The evolution of an effective pedagogy for teachers using the interactive whiteboard in mathematics and modern languages: an empirical analysis from the secondary sector', Learning, Media and Technology , 32(1), pp. 5-20.

Higgins, S., Falzon, C., Hall, I., Moseley, D., Smith, F., Smith, H. and Wall, K. (2005) Embedding ICT in the literacy and numeracy strategies : final report . Newcastle. [Online]. Available at: http://dro.dur.ac.uk/1899.

Hosokawa, Rikuya. Toshiki Katsura. PLoS One. (2018). Association between mobile technology use and child adjustment in early elementary school age. San Francisco Vol. 13, Iss. 7.
Kain (2004). The Integration of Instructional Technology into Public Education : Promises and Challenges. Educational Technology, 4(1),5-17

Kennewell, S. and Beauchamp, G. (2007) 'The features of interactive whiteboards and their influence on learning', Learning, Media and Technology , 32(3), pp. 227-241.

Lavy. (2002) Attitudes of students and teachers towards the use of Interactive whiteboards in EFL classrooms . Unpublished master thesis. Bilkent University, Ankara.

Lazzaros. M. (2003) The educational effects and implications of the interactive whiteboard strategy of Richardson primary school . ACT, Australia: Richardson Primary School.

Lee, M. and Boyle, M. (2003) The educational effects and implications of the interactive whiteboard strategy of Richardson primary school. ACT, Australia: Richardson Primary School.

Macedo, F. (2013) Teaching creative music technology in higher education: A phenomenological approach. Journal of Music, Technology \& Education , 6(2), 207-219. 
R. Kaufman (1998). The Internet as the ultimate technology and panacea. Educational Technology, JanuaryFebruary, 63-64.

Savage, J. (2007) Reconstructing music education through ICT Research in Education , 78, 65-77.

Siswono (2014). Pengembangan Kemampuan Berpikir Kritis dan Kreatif Siswa SMP dalam Matematika melalui Pendekatan Advokasi dengan Penyajian Masalah Open-Ended. Tesis Sekolah Pasca Sarjana UPI. Bandung: Tidak dipublikasikan.

Tilaar. 2000. Model-Model Pembelajaran Mengembangkan Profesionalisme
Guru. Jakarta: PT Raja Grafindo Persada.

Undang-Undang Republik Indonesia. No. 20 Tahun 2003 tentang Sistem Pendidikan Nasional (Sisdiknas) (2003). Departemen Pendidikan Nasional.

Wise, S. (2010) Teacher and student perceptions of digital technology in secondary school music education: a case study. e-journal of Studies in Music Education , 9(1), 46-60.

Zucker (2009). Transforming Schools With Technology, Independent Schools, Vol (68), No. (2) Winter Publisher: http://www.nais.org 